\title{
Conceptual Framework of Smart Banjar: A Synergize of The Micro-enterprise, Microfinance, and The Banjar Institution
}

\author{
I Dewa Made Adi Baskara Joni ${ }^{1, *}$, Shamsul Anuar Mokhtar², Bazilah A. Talip ${ }^{3}$ \\ ${ }^{1}$ Faculty of Economy and Business, Universitas Mahasaraswati, Denpasar, Indonesia \\ ${ }^{2}$ Malaysian Institute of Information Technology, Universiti Kuala Lumpur, Kuala Lumpur, Malaysia \\ ${ }^{3}$ Malaysian Institute of Information Technology, Universiti Kuala Lumpur, Kuala Lumpur, Malaysia \\ *Corresponding author.Email: dewadi.414@gmail.com
}

\begin{abstract}
The Banjar government system in Bali is believed to preserve the tradition and culture of the Balinese people. The Banjar has existed since the 10th-11th centuries. Affected by the COVID-19 Pandemic, Bali's economy in quarter 1 of 2020 experienced negative growth of $-1.14 \%$. Transactions that occur to meet the community's basic needs are not well managed - the community reliance on external. The synergy between micro-enterprise, microfinance, and the Banjar is very limited in strengthening the community's economy. Between them, the use of Information Communication Technology (ICT) is deficient. The Banjar role needs to be enhanced to maintain the resilience of the Balinese people in the economy. Entrepreneurship can be developed because it has been proven to improve people's welfare. This research aims to develop a framework that allows the synergy of microenterprise, microfinance, and the Banjar using ICT as an enabler to reduce external parties' reliance on the community's basic needs. The organizational level technology adoption theory is used to develop the conceptual framework. The Technology-Organization-Environment (TOE) framework is considered to have the most relevance in this research. The conceptual framework of Smart Banjar defines in the three contexts of the TOE framework. The Advisory board is an environmental context that will form the policies in the Smart Banjar framework. The organizational context will synergize micro-enterprise, microfinance, and the Banjar. The technological context will support Smart Banjar to achieve its goals. It can happen with the existence of ICT infrastructure, ICT services, and ICT literacy with their respective components.
\end{abstract}

\section{Keywords: Smart Banjar, Micro-enterprise, Microfinance, The Banjar, ICT Adoption Framework}

\section{INTRODUCTION}

Indonesia is one of the developing countries in the region of Southeast Asia (ASEAN). Indonesia is an archipelago divided into administrative regions totaling 34 provinces [1]. Bali is one of the provinces in Indonesia. Like other provinces, Bali has a government structure from the highest level to the lowest. The governance structure starts from the Provinsi (Provincial), Kabupaten or Kota (Regency or City), Kecamatan (District), to the Desa or Kelurahan (Village). However, Bali is unique in other provinces. There are two types of villages in Bali: the Desa Adat (Customary Village) and the Desa Dinas (Official Village). Customary Villages and Official Village in Bali have been known for a long time. The village government system has been a Balinese people tradition since the kingdom era [2]. The lowest government level under the Village is the Banjar led by Kelian Banjar [3], [4]. The Banjar has existed since the 10th-11th centuries [5], [6]. The Banjar government system is believed to preserve the tradition and culture of the Balinese people.

The Customary Village and Banjar Adat have special autonomy rights and can manage their households.
Banjar Adat can manage the tradition, religious and socio-economic activities of the community. In some Banjar, especially those in urban areas and tourism areas, it has Bale Banjar (a place where people carry out traditional activities) that have expanded their functions for economic activities [4], [7]. Along with these developments, Banjar with Bale Banjar as a public space continues to perform its primary function as a fortress guarding tradition and socio-cultural society. Thus the effects that occur can provide benefits to the community [6]. With its traditions and culture, Bali has become a world tourism destination with a significant economic impact.

Behind the sparkling tourism of Bali, there are still problems with poverty. The percentage of poor people in Bali in March 2019 is 3.79\% [8]. The welfare of the people in Bali is uneven and only focused on specific areas. This situation is exacerbated by the world health disaster, Coronavirus Disease 2019 (COVID-19) pandemic. The COVID-19 pandemic had a severe impact on the tourism sector and the Bali economy. The government said the Bali province was damaged by COVID-19, where all tourist activities stopped. At least $96 \%$ of hotels were temporarily closed [9]. For months 
the tourism destinations, accommodation, food and beverage providers, and supporting industries were forced to stop operating. Affected by the COVID-19 Pandemic, Bali's economy in the first three months (quarter 1) of 2020 experienced negative growth of $1.14 \%$, which was even lower than the national rate of $2.97 \%$. That means the first negative growth in the last ten years [10]. A survey stated that $66.53 \%$ of Balinese people experienced a decrease in income, and $81.82 \%$ indicated their savings began to decrease. As many as $50.83 \%$ of the Balinese stated that they had difficulty getting food, and $21.01 \%$ of them were forced to pile up food at home [9].

Tourism in Bali relies on Village and Banjar as the foremost fortress in preserving the culture and tradition that currently the object of tourism. The role of Village and Banjar that impact tourism development should positively affect Bali people's welfare. As the lowest governance structure and indigenous community, the Banjar's role needs to be enhanced to maintain the Balinese people's resilience in the economy. The Banjar government can collaborate with financial institutions to ensure sustainability and improve the Balinese people's economy. According to the Bali Provincial Regulation Number 4 the Year 2019 regarding Customary Villages (Desa Adat), Labda Pacingkreman Desa Adat, referred to as LPD, is a Village Credit Institution owned by Customary Village which is domiciled in Customary Village.

Currently, there are Village Credit Institutions (Lembaga Perkreditan Desa or LPD) and Koperasi as microfinance institutions in Bali. LPD, as a microfinance institution, is a unique business entity. LPD only exists in Bali and is managed based on Balinese cultural philosophy [11]. If viewed from the history of the formation and principles of the LPD and Koperasi, the microfinance institution should resolve the community's economic problems. The existence and role of LPD's are needed in forming micro and small enterprises to boost the economy of the rural community [12]. However, many people are still lacking and even classified as poor because they do not have access to these financial institutions. That is because programs in the Banjar government have lack integration with existing programs in microfinance institutions. The program's integration can carry the concept of "Smart Village" with a more appropriate structure, namely "Smart Banjar".

Innovation by developing the concept of "Smart Banjar" can increase the capacity and role of the Banjar. The increase is to be able to ensure the economic sustainability of the community. In this digital era, innovation with the support of technology can be integrated with Balinese culture [13]. Banjar can manage citizen data with more valuable such as the purchasing power of each citizen. The data can be integrated with microfinance institutions so that economic turnover occurs as expected. Every residents' house, which consists of several people, must have its primary and secondary needs. Those needs should be fulfilled by residents who have appropriate business activities (microenterprises). The reality is that the supply and demand relationship is not yet fully formed. Transactions spread outside the Banjar environment and even the village environment. Likewise, with money circulating in the transaction. If a micro-financial institution (LPD and Koperasi) is involved in managing this transaction, the transaction profits can be returned to the citizens in the form of share-profits or dividends. A synergy between Banjar, Microenterprise, and Microfinance is needed to make this happen.

The synergy between Banjar, microenterprise, and microfinance can be done by developing a framework. The Framework involves technology, in this case, Information Communication Technology (ICT). Application of ICT to maximize the performance function of each element. This research will develop an ICT adoption framework in the Smart Banjar concept. That concept by synergizing the existing microenterprise, microfinance, and the Banjar itself.

\section{LITERATURE REVIEW}

Smart Banjar is a technological innovation concept that has never existed. Developing the Smart Banjar concept will involve various entities, community groups, and even various stakeholders and related organizations. Technological innovation is neither a single event nor even a small number of discrete events. Technological innovation involves a rich embroidery of events: many activities, many decisions, and many bits of behaviour on the part of individuals and social units, most of whom are not even self-consciously aware of being part of such a process [14].

TPB, TAM, and UTAUT theories are the most frequently used models or frameworks. However, these theories analyze the technology adoption process at the individual level [15], [16]. At the organizational level, the technology adoption process has three theories: DOI, TOE, and IT [15]. DOI and TOE are technology adoption theories at the firm level [16]. The ICT adoption theories are mapped in table 1 below. 
Table 1. Mapping of ICT Adoption Theories

\begin{tabular}{|c|c|c|c|c|c|c|c|}
\hline \multirow{2}{*}{ No. } & \multirow{2}{*}{ Framework Name } & \multirow{2}{*}{$\begin{array}{l}\text { Authors } \\
\text { (Year) }\end{array}$} & \multicolumn{2}{|c|}{ Unit of Analysis } & \multicolumn{3}{|c|}{ Level of Relevance } \\
\hline & & & $\begin{array}{l}\text { Individual } \\
\text { Level }\end{array}$ & $\begin{array}{c}\text { Organizational } \\
\text { Level }\end{array}$ & Low & Moderate & High \\
\hline 1 & $\begin{array}{l}\text { Theory of Planned } \\
\text { Behavior (TPB) }\end{array}$ & $\begin{array}{l}\text { Ajzen (1985, } \\
1991)\end{array}$ & $\checkmark$ & & $\checkmark$ & & \\
\hline 2 & $\begin{array}{l}\text { Technology } \\
\text { Acceptance The } \\
\text { model (TAM) }\end{array}$ & $\begin{array}{l}\text { Davis, } \\
\text { Bogozzi and } \\
\text { Warshaw } \\
(1989)\end{array}$ & $\boldsymbol{\nu}$ & & & $\checkmark$ & \\
\hline 3 & TAM2 & $\begin{array}{l}\text { Vankatesh and } \\
\text { Davis (2000) }\end{array}$ & $\boldsymbol{\nu}$ & & & $\checkmark$ & \\
\hline 4 & TAM3 & $\begin{array}{l}\text { Vankatesh and } \\
\text { Bala (2008) }\end{array}$ & $\checkmark$ & & & $\checkmark$ & \\
\hline 5 & $\begin{array}{l}\text { Unified Theory of } \\
\text { Acceptance and Use } \\
\text { of Technology } \\
\text { (UTAUT) }\end{array}$ & $\begin{array}{l}\text { Vankatesh, } \\
\text { Morris, Davis } \\
\text { and Davis } \\
(2003)\end{array}$ & $\boldsymbol{V}$ & & $\checkmark$ & & \\
\hline 6 & $\begin{array}{l}\text { Diffusion of } \\
\text { Innovation (DOI) }\end{array}$ & Rogers (1995) & & $\boldsymbol{v}$ & $\boldsymbol{V}$ & & \\
\hline 7 & $\begin{array}{l}\text { Technology- } \\
\text { Organization- } \\
\text { Environment (TOE) }\end{array}$ & $\begin{array}{l}\text { Tornatzky and } \\
\text { Fleischer } \\
\text { (1990) }\end{array}$ & & $\boldsymbol{V}$ & & & $\checkmark$ \\
\hline 8 & $\begin{array}{l}\text { Institutional Theory } \\
\text { (IT) }\end{array}$ & $\begin{array}{l}\text { Scott and } \\
\text { Christensen } \\
\text { (1995) }\end{array}$ & & $\checkmark$ & $\checkmark$ & & \\
\hline
\end{tabular}

Can be seen in table 1 above, a mapping of existing ICT adoption theories. Unit of analysis is used to determine the level of use of the theory. Whether at the individual or organizational level. Furthermore, the level of relevance is made into three levels starting from low, moderate, and high. Based on the mapping, it can be concluded that a unit of analysis is needed at the organizational level for the development of a conceptual framework, and the level of relevance is high. Therefore, Technology-Organization-Environment (TOE) is the ICT adoption theory that has been used.

In this research, the basic theory that is the basis for developing the framework is TOE. TOE framework is a theory of technology adoption developed by Tornatzky and Fleischer in 1990. In the TOE framework, there are three key contexts. The first is the technological context. According to [17], the technological context represents the existing technology and the alignment of the latest technologies relevant to the organization (i.e., internal and external technologies) [15]. The second is the organizational context. According to [17], organizational context relates to the size and range of the organization (i.e., scope, size, and managerial structure) [15]. The third is the environmental context. According to [17], the environmental context of an area in which a company does business (i.e., industry, competitors, and government regulation) [15].

The TOE framework is a generic theory which only mentions several dimensions that influence technology adoption. The TOE framework can be adapted without specifying the factors for each dimension. Researchers can choose the factors from each dimension according to the innovation's characteristics and the organization itself [18]. The Smart Banjar concept involves a fairly complex internal and external organizational structure. This is because Banjar is a traditional or customary community at the same time as an official structure. Several reasons are the justification for this research to use TOE as a basic framework: 1. The Smart Banjar concept involves the Banjar structure, Microenterprise, and Microfinance to work together. Therefore, TOE is a suitable framework for applying a technological innovation that involves internal and external organizations; 2. The TOE framework has been used in various studies related to Smart Village, Smart Rural, and Smart City. The TOE framework is also used to analyze the readiness to adopt new technologies that require synergy between the community, government, and professionals who manage these innovations; 3 . The context of technology, organization, and environment is considered comprehensive to cover all Smart Banjar concept elements.

\section{METHOD}

This research presents a critical review of the literature. The systematic literature review aims to justify and broad observations about what researchers have produced in recent years. The systematic literature review is directed according to the topic discussed and will answer the research questions as well as the objectives of this study. 
With the systematic literature review, it is hoped that the reader more clearly sees the existing research gap. Thus, researchers will get the legitimacy of the contributions made in this study to the body of knowledge. A systematic literature review is carried out by exploring three aspects or elements based on the problem statements.

Searching for aspects or elements is carried out by searching for research articles in various databases. These databases include the IEEE, Ebscohost, Google Scholar, and ScienceDirect. Based on the search results, 28 studies related to aspects or elements of the Smart Banjar Concept were obtained. Below are the keywords and phrases used in searches.

Table 2. Keywords and Phrases

\begin{tabular}{|c|c|}
\hline Concepts & Keyword or Phrases \\
\hline The Banjar & $\begin{array}{l}\text { traditional Bale Banjar adat, Bale } \\
\text { Banjar, socio-cultural existence, } \\
\text { Banjar } \quad \text { suka } \\
\text { customary sanctions, sanksi adat }\end{array}$ \\
\hline $\begin{array}{l}\text { Micro } \\
\text { Enterprise }\end{array}$ & $\begin{array}{l}\text { IT adoption of microenterprise, } \\
\text { microenterprise, micro-enterprise, } \\
\text { micro-entrepreneurs, small } \\
\text { business, rural micro-enterprises, } \\
\text { micro enterprise }\end{array}$ \\
\hline Micro Finance & $\begin{array}{l}\text { micro finance, } \\
\text { institution, microfinance, village } \\
\text { credit union, village } \\
\text { institution, } \\
\text { management }\end{array}$ \\
\hline $\begin{array}{l}\text { The Banjar and } \\
\text { Micro } \\
\text { Enterprise }\end{array}$ & $\begin{array}{l}\text { micro-business, economic } \\
\text { contribution, local communities, } \\
\text { Bale Banjar, economics }\end{array}$ \\
\hline $\begin{array}{l}\text { Micro } \\
\text { Enterprise and } \\
\text { Micro Finance }\end{array}$ & $\begin{array}{lr}\text { micro-enterprises, } & \text { microfinance, } \\
\text { microcredit, } & \text { microenterprise } \\
\text { performance, } & \text { BUMDesa, } \\
\text { microcredit schemes } & \\
\end{array}$ \\
\hline $\begin{array}{l}\text { Micro Finance } \\
\text { and The Banjar }\end{array}$ & $\begin{array}{l}\text { harmonious culture, financial } \\
\text { performance, micro finance } \\
\text { institution, cultural harmony, } \\
\text { village credit institution, LPD } \\
\text { Function }\end{array}$ \\
\hline \multicolumn{2}{|c|}{$\begin{array}{l}\text { Sources: } \\
\text { Gantini and Hanan, 2016; Sawitri and Nugrahandika, } \\
\text { 2017; Suwardani et al, 2018; Kurniawati, 2018; } \\
\text { Widnyana, 2019; Winiasih et al, 2019; Khan et al, } \\
\text { 2016; Huang et al, 2019; Anwar et al, 2019; Räisänen } \\
\text { and Tuovinen, 2020; Sandberg and Håkansson 2020; } \\
\text { Harefa, 2016; Agbola et al, 2017; Sadiartha, 2017; } \\
\text { Sundarianingsih et al, 2018; Purnamawati and } \\
\text { Adnyani, 2020; Leavell, 2010; Sari and Sri, 2017; } \\
\text { Suryawati et al, 2018; Hameed et al, 2017; Tammili et } \\
\text { al, 2017; Atmaja et al, 2018; Suprapto et al, 2019; } \\
\text { Mustapa et al, 2019; Astawa et al, 2016; Astawa et al, } \\
\text { 2016a; Sudemen and Anggriyani, 2017; Junaedi et al, } \\
\text { 2019. }\end{array}$} \\
\hline
\end{tabular}

The search for research publications on the topics was carried out in the 2016-2020 range. The number of studies conducted on each topic and its intersect vary widely. The quality and substance of the relationship between previous research and the research that carried out are the basis for selecting the research used as a reference. Below is the suitability of the topics (aspects or elements) of the 28 reviewed research.

Table 3. Suitability of the Topics

\begin{tabular}{|c|c|c|c|c|c|c|}
\hline \multirow{2}{*}{ Authors } & \multicolumn{6}{|c|}{ Concepts } \\
\hline & A & B & $\mathrm{C}$ & $\mathrm{D}$ & $\mathrm{E}$ & $\mathrm{F}$ \\
\hline $\begin{array}{l}\text { Gantini and } \\
\text { Hanan, } 2016\end{array}$ & $\checkmark$ & & & & & \\
\hline $\begin{array}{l}\text { Sawitri and } \\
\text { Nugrahandika, } \\
2017\end{array}$ & $\checkmark$ & & & & & \\
\hline $\begin{array}{l}\text { Suwardani et } \\
\text { al., } 2018\end{array}$ & $\checkmark$ & & & & & \\
\hline $\begin{array}{l}\text { Kurniawati, } \\
2018\end{array}$ & $\checkmark$ & & & & & \\
\hline Widnyana, 2019 & $\nu$ & & & & & \\
\hline $\begin{array}{l}\text { Winiasih et al., } \\
2019\end{array}$ & $\checkmark$ & & & & & \\
\hline $\begin{array}{l}\text { Khan et al., } \\
2016\end{array}$ & & $\checkmark$ & & & & \\
\hline $\begin{array}{l}\text { Huang et al., } \\
2019\end{array}$ & & $\boldsymbol{V}$ & & & & \\
\hline $\begin{array}{l}\text { Anwar et al., } \\
2019\end{array}$ & & $\checkmark$ & & & & \\
\hline $\begin{array}{l}\text { Räisänen and } \\
\text { Tuovinen, } 2020\end{array}$ & & $\checkmark$ & & & & \\
\hline $\begin{array}{l}\text { Sandberg and } \\
\text { Håkansson } \\
2020\end{array}$ & & $\checkmark$ & & & & \\
\hline Harefa, 2016 & & & $\nu$ & & & \\
\hline $\begin{array}{l}\text { Agbola et al., } \\
2017\end{array}$ & & & $V$ & & & \\
\hline Sadiartha, 2017 & & & $\checkmark$ & & & \\
\hline $\begin{array}{l}\text { Sundarianingsih } \\
\text { et al, } 2018\end{array}$ & & & $\boldsymbol{V}$ & & & \\
\hline $\begin{array}{l}\text { Purnamawati } \\
\text { and Adnyani, } \\
2020\end{array}$ & & & $\boldsymbol{V}$ & & & \\
\hline Leavell, 2010 & $\checkmark$ & $\nu$ & & $\checkmark$ & & \\
\hline $\begin{array}{l}\text { Sari and Sri, } \\
2017\end{array}$ & $\checkmark$ & $\checkmark$ & & $\boldsymbol{V}$ & & \\
\hline $\begin{array}{l}\text { Suryawati et al., } \\
2018\end{array}$ & $\boldsymbol{V}$ & $\checkmark$ & & $\checkmark$ & & \\
\hline $\begin{array}{l}\text { Hameed et al., } \\
2017\end{array}$ & & $\boldsymbol{V}$ & $\boldsymbol{V}$ & & $\checkmark$ & \\
\hline $\begin{array}{l}\text { Tammili et al., } \\
2017\end{array}$ & & $\checkmark$ & $\checkmark$ & & $\checkmark$ & \\
\hline $\begin{array}{l}\text { Atmaja et al., } \\
2018\end{array}$ & & $\boldsymbol{V}$ & $\boldsymbol{V}$ & & $\boldsymbol{V}$ & \\
\hline $\begin{array}{l}\text { Suprapto et al., } \\
2019\end{array}$ & & $\checkmark$ & $\boldsymbol{V}$ & & $\checkmark$ & \\
\hline
\end{tabular}




\begin{tabular}{|c|c|c|c|c|c|c|}
\hline \multirow{2}{*}{ Authors } & \multicolumn{6}{|c|}{ Concepts } \\
\hline & A & B & $\mathrm{C}$ & $\mathrm{D}$ & $E$ & $\mathrm{~F}$ \\
\hline $\begin{array}{l}\text { Mustapa et al., } \\
2019\end{array}$ & & $\checkmark$ & $\boldsymbol{V}$ & & $\checkmark$ & \\
\hline $\begin{array}{l}\text { Astawa et al., } \\
2016\end{array}$ & $\checkmark$ & & $\checkmark$ & & & $\boldsymbol{V}$ \\
\hline $\begin{array}{l}\text { Astawa et al., } \\
2016 \mathrm{a}\end{array}$ & $\checkmark$ & & $\checkmark$ & & & $\boldsymbol{V}$ \\
\hline $\begin{array}{l}\text { Sudemen and } \\
\text { Anggriyani, } \\
2017\end{array}$ & $v$ & & $\checkmark$ & & & $\checkmark$ \\
\hline $\begin{array}{l}\text { Junaedi et al., } \\
2019\end{array}$ & $\boldsymbol{v}$ & & $\checkmark$ & & & $\boldsymbol{V}$ \\
\hline $\begin{array}{l}\text { Concepts: } \\
\text { A: The Banjar } \\
\text { B: Micro Enterpri } \\
\text { C: Micro Finance } \\
\text { D: The Banjar an } \\
\text { E: Micro Enterpri } \\
\text { F: Micro Finance }\end{array}$ & $\begin{array}{l}\text { Mic } \\
\text { se an } \\
\text { and T }\end{array}$ & $\begin{array}{l}\text { o En } \\
\text { Mic }\end{array}$ & $\begin{array}{l}\text { pris } \\
\text { Fina } \\
\text { ar }\end{array}$ & & & \\
\hline
\end{tabular}

Those three aspects or elements are researched and studied. The search was carried out more deeply in the research that intersected with the topics of The Banjar and Micro Enterprise (B\&ME), Micro Enterprise and Micro Finance (ME\&MF), and also Micro Finance and The Banjar (B\&MF). A search has been carried out, so it has been found that no research (very limited) intersects the three topics directly. It is the novelty of this research to form the synergy of Microenterprise, Microfinance, and The Banjar into a Smart Banjar Concept. Below are the areas of the systematic literature review on the Smart Banjar Concept.

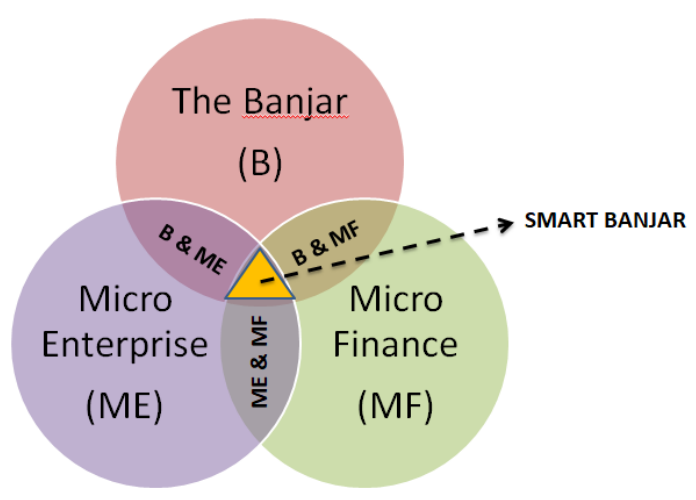

Figure 1 Systematic Literature Review Areas

\section{RESULT AND DISCUSSION}

Banjar is a social structure as well as a government structure that only exists in Bali. Although only in Bali, this local wisdom is well known in foreign countries. The Banjar is believed to be an ancestral heritage that can maintain traditions and adapt from time to time. Banjar's continuity and the people's empowerment can be done by carrying out a smart concept. Currently, existing research tends to develop Smart City and Smart Village. However, no research has developed the Smart Banjar concept. Smart City's concept can be applied on a smaller or larger scale, provided a community must be served [19]. According to [19], the application of a smart concept can be started from the smallest scope, namely Smart Village, then Smart District, Smart City, up to the largest scope, namely the Country. Based on this, it is deemed necessary to initiate the development of a smart concept to serve the smallest social community in Bali, namely Banjar. The conceptual framework of Smart Banjar will be explained in three contexts as follows.

\subsection{Technology Context}

The synergy of the Banjar, Microenterprise, and Microfinance elements will be realized effectively and efficiently with ICT adoption support. Essential services and local economic potential-based services can be developed and optimize with ICT services. In order for these services to run optimally, it is necessary to develop an ICT infrastructure from the user and service provider levels. The ICT mastery for the community as users and service providers as operators need to be improved continuously. The components required are the internet network and electrical reliability. Based on this, ICT literacy is important for successfully adopting ICT in the Smart Banjar concept. The components needed are internet users, ICT used, digital device ownership, and strategic guidelines. The overall elements above are the technological context of Smart Banjar Version 1.0.

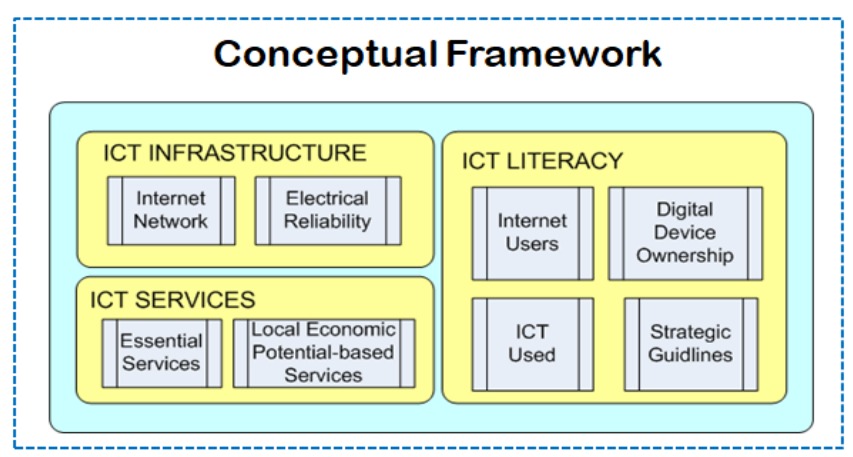

Figure 2 Technology Context of The Smart Banjar Version 1.0

\subsection{Organization Context}

The Banjar institutions at the government level are under the village government. The policies needed to collaborate between Banjar can be carried out directly at the village level. Accordingly, the organizational context of Smart Rural's concept adapted and adjusted to Smart Banjar's concept. In one village there are several Banjar. The village government will oversee several Banjar in their area. Within a Banjar, various community-owned businesses (including village-owned or Banjar-owned) are classified as microenterprises. Microfinance will support the funding, in this case, LPD or village-owned cooperatives, Banjar, or community. All of these elements will work together to fulfill daily needs and 
improve community welfare. The overall elements above are the organizational context of the Smart Banjar Version 1.0.

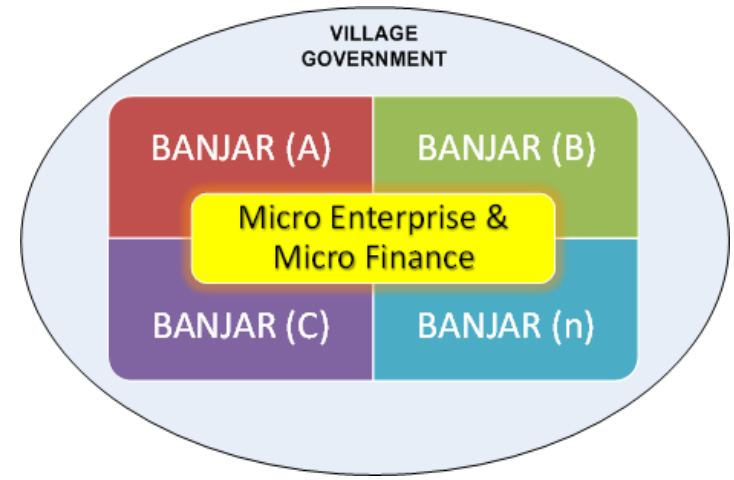

Figure 3 Organization Context of The Smart Banjar Version 1.0

\subsection{Environment Context}

The advisory board is the environmental context of the Smart Banjar 1.0. The advisory board is an institution formed to minimize obstacles in implementing Smart Banjar. The advisory board will collaborate and provide the necessary support. The advisory board is an external environment that plays a role in giving advice.

The advisory board consists of: 1.Village deliberation agency (VDA) is a parliamentary institution at the village level. This institution is a representation of the villagers as a liaison in conveying aspirations. VDA will ensure that the implementation of village development runs well and democratically; 2.Central \& local government is a government agency at every level. The role of this institution is in the related regulations and policies; 3.Customary institutions are institutions at the Village and Banjar levels. The role of this institution is to adjust related regulations and policies to suit local wisdom and support the Smart Banjar concept; 4. The nongovernment organization is an institution that assists in monitoring and implementing the Smart Banjar concept; 5. Research institutions are institutions that can review the sustainability of the application of the Smart Banjar concept. These institutions can develop related programs and provide information and knowledge to support the successful application of sustainable concepts; 6 . Educational institutions are institutions that will assist in the development of quality human resources.

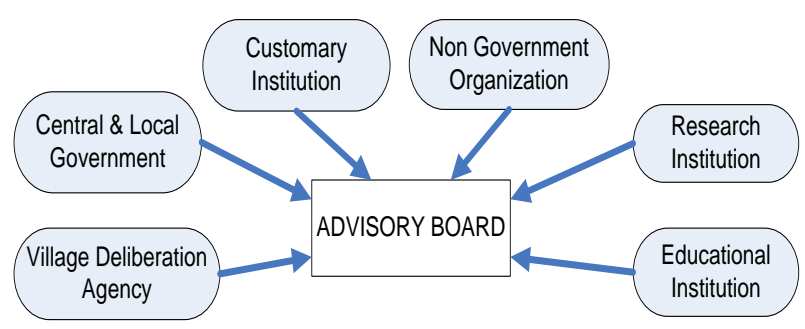

Figure 4 Environment Context of The Smart Banjar 1.0

\section{CONCLUSION}

A systematic literature review has been carried out. Although the Smart Banjar concept is a concept that has never existed, it can fundamentally refer to the Smart Village and Smart Rural concepts in Indonesia. In terms of social and governmental structures, Banjar is under the village. The Smart Banjar concept version 1.0 adapts the research [19]-[23]. In this Smart Banjar concept, ICT adoption is part of the concept. TOE is a technology adoption framework used as the basis for developing a framework in this research. The Smart Banjar concept version 1.0 has three contexts. The first is the technological context. In the context of technology, there are three entities. The first entity is ICT Infrastructure which has two components, namely Internet Network and Electrical Reliability. The second entity is ICT Services, which has two components: Essential Services and Local Economic Potential-based Services. The third entity is ICT Literacy, which has four components: Internet Users, ICT Used, Digital Device Ownership, and Strategic Guidelines. In the organizational context, there is a Village Government that covers all Banjar within its jurisdiction. The microenterprises and microfinance in each Banjar and Village work together to achieve the Smart Banjar goal. In the context of the environment, an Advisory Board is formed, which will play an active role in formulating policies that will encourage good governance. The advisory board consists of village deliberation agencies, central \& local governments, customary institutions, non-government organizations, research institutions, and educational institutions.

\section{REFERENCES}

[1] Indonesia.go.id, "Pemerintah Provinsi," Indonesia.go.id, 2017. [Online]. Available: https://www.indonesia.go.id/province.

[2] I. G. Parimartha, Silang Pandang Desa Adat dan Desa Dinas di Bali. Denpasar: Udayana University Press, 2013.

[3] I. W. Suasnawa, I. M. S. A. Jaya, and I. B. K. Sugirianta, "PKM PENGELOLAAN KEUANGAN BANJAR ADAT DI DESA SANGEH , PROVINSI BALI," J. BHAKTI PERSADA, vol. 4, no. 2, pp. 65-75, 2018.

[4] N. P. Suwardani, W. Paramartha, and I. G. A. Suasthi, "BALE BANJAR AND ITS IMPLICATIONS ON THE EXISTENCE OF BALI SOCIOCULTURAL COMMUNITIES," in PROCEEDING BOOK INTERNATIONAL SEMINAR ON TOLERANCE AND PLURALISM IN SOUTHEAST ASIA THE FACULTY OF RELIGIOUS AND CULTURAL SCIENCE, 2018, pp. 83-90.

[5] A. A. N. A. Sanjaya and I. N. H. Juliarthana, "Pemanfaatan Bale Banjar Sebagai Ruang Kreativitas Anak Muda Di Kota Denpasar," J. 
Sp., vol. 1, no. 1, pp. 26-32, 2019.

[6] N. P. A. Sawitri and W. H. Nugrahandika, "TIPOLOGI PERKEMBANGAN PEMANFAATAN LAHAN BALE BANJAR DAN FAKTOR-FAKTOR YANG MEMENGARUHINYA Studi Kasus Kota Denpasar , Provinsi Bali," in Seminar Nasional Space \#3, 2017, pp. 352-376.

[7] C. Gantini and H. Hanan, "The Impact of Tourism Industry on the Sustainability of Traditional Bale Banjar in Denpasar," in Proceedings of the 6th International Conference of Arte-Polis, 2017, no. May 2018.

[8] Central Bureau of Statistics Bali Provinces, "Profil Kemiskinan di Bali Maret 2019," Denpasar, 2019.

[9] I. G. A. D. Yuniti, N. Sasmita, L. L. Komara, J. H. Purba, and N. P. Pandawani, "The Impact of Covid-19 on Community Life in the Province of Bali , Indonesia," vol. 24, no. 10, pp. 1918-1929, 2020 .

[10] A. G. H. Hermawan, PERKEMBANGAN TRIWULANAN EKONOMI BALI TRIWULAN I 2020. BPS Provinsi Bali, 2020.

[11] I. G. A. Purnamawati and N. K. S. Adnyani, "Performance evaluation of microfinance institutions and local wisdom-based management concept," Manag. Sci. Lett., vol. 10, no. 1, pp. 143-152, 2020.

[12] M. Harefa, "Development, Challenge and Policy Perspective Development of Rural Micro Finance Institution of Bali as Financial Intermediate," Kajian, vol. 21, no. 4, pp. 339357, 2016.

[13] P. N. Riastini, A. Widowati, Y. Ratnasari, and I. Darma, "Enganging Balinese Culture and Technology in Digital Era: A Review to Foster Primary Teachers' Competencies," in Advances in Social Science, Education and Humanities Research (ASSEHR), 2019, vol. 330, no. Iceri 2018, pp. 244-248.

[14] L. . Tornatzky and M. Fleischer, The Processes of Technological Innovation. Lexington: Lexington Books, 1990.

[15] S. Molinillo and A. Japutra, "Organizational adoption of digital information and technology: a theoretical review," Bottom Line, vol. 30, no. 1, pp. 33-46, 2017.

[16] T. Oliveira and M. F. Martins, "Literature Review of Information Technology Adoption Models at Firm Level," Electron. J. Inf. Syst. Eval., vol. 14, no. 1, pp. 110-121, 2011.

[17] S. F. Handayani and E. R. Mahendrawathi,
"Antecedent and business process management non-technical capabilities in social media implementation for micro, small and medium enterprises: A conceptual model," Procedia Comput. Sci., vol. 161, pp. 1114-1121, 2019.

[18] M. A. A. Dewi, A. N. Hidayanto, B. Purwandari, M. Kosandi, and N. F. A. Budi, "Smart City Readiness Model Using on TechnologyOrganization-Environment (TOE) Framework and Its Effect on Adoption Decision," in Proceedings of the 22nd Pacific Asia Conference on Information Systems - Opportunities and Challenges for the Digitized Society: Are We Ready?, PACIS 2018, 2018.

[19] R. N. Andari and S. Ella, "PENGEMBANGAN MODEL SMART RURAL UNTUK PEMBANGUNAN KAWASAN PERDESAAN DI INDONESIA DEVELOPING A SMART RURAL MODEL FOR RURAL AREA DEVELOPMENT IN INDONESIA,” J. Borneo Adm., vol. 15, no. 1, pp. 41-58, 2019.

[20] A. A. Aziiza and T. D. Susanto, "The Smart Village Model for Rural Area ( Case Study: Banyuwangi Regency )," als Sci. Eng., no. 722, 2020.

[21] S. Ella and R. N. Andari, "Developing a Smart Village Model for Village Development in Indonesia," in 2018 International Conference on ICT for Smart Society (ICISS), 2018, pp. 1-6.

[22] S. Ella and R. N. Andari, "Utilization of ICT in Building a Smart Village Model for Village Development in Indonesia," in 2019 International Conference on ICT for Smart Society (ICISS), 2019.

[23] I. Y. Mukti, M. E. Iacob, A. Aldea, R. Govindaraju, and J. Van Hillegersberg, Defining Rural Smartness and Its Impact: A Systematic, no. 0123456789. Springer US, 2021. 